\title{
SALES PROMOTION AS A DETERMINING FACTOR IN THE COMPETITIVE POSITION OF THE COMPANY
}

\author{
UDC: $658.82: 339.137 .2$ \\ Original Scientific Paper \\ Đorđe ALAVUK ${ }^{1}$, Jelena JEVTIĆ ${ }^{2}$, Ivana PETREVSKA ${ }^{3}$ \\ ${ }^{1}$ High School of Technology, Hajduk Veljkova 10, 15000 Šabac, Republic of Serbia \\ E-mail: djordjealavuk@yahoo.com \\ ${ }^{2}$ High School of Technology, Hajduk Veljkova 10, 15000 Šabac, Republic of Serbia \\ ${ }^{3}$ American University in Bosnia and Herzegovina, College of Economics, Mije Keroševića Guje 3, 7500 Tuzla, \\ Bosnia and Herzegovina
}

Paper received: 25.04.2015.; Paper accepted: 23.05.2015.

\begin{abstract}
Increased competition, globalization, numerous changes in the field of engineering and technology are just some of the changes that accompany modern business conditions. Modern consumers are increasingly demanding. Individuals vary greatly within groups and cultures to which they belong, but also among themselves based on the characteristics that distinguish them. People engaged in marketing have to constantly monitor and measure consumer attitudes so that their needs and desires are fully met. This paper summarizes the sales promotion activities carried out by retail chains. The aim of the activities of sales promotion is to create and maintain long-term relationships with customers and competitive advantage on the market. The research topic is the impact of sales promotion activities on the behavior and attitudes of consumers when choosing a product. The aim of the research is to examine the effects achieved by sales improvement to consumers through the implementation of the competitive positions of the companies. For the purpose of the research the method used was survey research.
\end{abstract}

Keywords: sales, sales promotion, competition, consumer, product.

\section{INTRODUCTION}

Business bidder largely has to focus on prediction to a great extent, satisfaction and understanding of the specific needs and demands of the consumers. In modern conditions of globalization and increased competition the companise are constantly struggling to retain and win over new customers. The modern consumers lead a complex life and no longer follow one pattern of behavior, but form attitudes and behavior depending on the situation they are in. An attitude can be conceptualized as a psychological tendency which is manifested by placing materialized behavior that was established on the basis of an opinion about an object that is moving in the range from positive to negative. Attitudes can take three forms: opinions, expressing emotions and failures (Begen, 2004). Over time, consumer behavior begins to differ between the groups to which they belong, as well as individually. Companies use tools for sales promotion when they want to achieve in the short run acceleration or increase of sales to customers. At a time of increased competition when most companies apply sales promotion activities, it is crucial to be the first and innovative. When profitable growth is defined as a goal then it means to build customer loyalty by offering them an additional value (Stanković et al., 2012).

The increase in sales during a short period of time to reduce inventory or to achieve a financial plan before the deadline is an important objective of sales promotion activities conducted by the company. The companies that compete with each other over a long period bind customers to themselves through the entire sales promotion activities, thereby increasing the frequency of repeated purchases during the promotion period (Jobber and Fahy, 2006). 


\section{IMPROVING SALES AS AN ACTIVE PART OF PROMOTION}

By selling products companies mostly come into direct contact with the consumers for the first time, which provokes different reactions. As sales represents an inevitable phase of the cycle of reproduction so is its improvement an important form of promotion as an instrument of the marketing mix. Consumers are constantly in a position to choose between two or more alternatives, where the decisions by itself means the intention of consumers to purchase products and services and meet the specific needs and desires (Maričić, 2008). The promotional activities include different set of targets oriented communication with stakeholders in order to achieve the desired image in the public that will contribute to the realization of the planned business objectives. Promotion is an effective way of influencing the results of the operations of business organizations. The role of promotion in marketing program is of dynamic character, which means that there is no defined promotion of combined marketing mix, even for businesses or for products of a production program, but they are subject to change as well as the other instruments of the marketing mix (Božidarević and Salai, 2009). The promotional activities also include advertising, sales increase, personal selling, publicity and public relations (Šapić, 2002).

Activities of sales increase stimulate consumers to try products, sellers use promotion as an incentive instrument to promote in order to attract new customers, reward loyal customers and increase the rate of repurchase of occasional users. Companies in the competitive contest implement the sales promotion activities to obligate themselves to those consumers who go from one to another brand and who primarily search for low prices. These activities encourage the sale of products and services, and thus the economic effects of trade and production with esthetic decoration of shop windows, interior and exterior sale points, contributing to the rationalization of work in the store and helps customers to more quickly and more comfortably choose and buy certain products.

The development of a large number of supermarkets and megamarkets is growing and the need for more aggressive promotion activities which compete with competitors for a place on the shelf. Actions for sales promotion, in combination with other agents of marketing communication, link manufacturers with customers at sale points regardless of where the customer was located (Smith, 2002).

\section{INSTRUMENTS FOR STIMULATING CONSUMERS IN DECISIONMAKING ABOUT PRODUCT SELECTION}

Activities of sales promotion may be directed at consumers and business customers. Some of the forms of promotional activities which are intended for final users are: samples, coupons, discounts, premiums and a variety of rewards for regular purchases. Much of the promotional budget is invested in instruments improving sales to commercial customers $46.9 \%$ while the same activities to consumers amount to $27,9 \%$ (Kotler and Keller, 2006). According to the type of product , the company has to set goals, to choose the means to develop the program and carry out pre-testing of the same, implement and control it.

The reduction of prices as a sales promotion techniques, which is precisely time limited, is a primary stimulant during consumer decisions about the purchase. Bearing in mind that the price is one of the differentiating parameters which determines the consumer's choice, the companies use it in order to conquer new and gain more competitive position in existing markets.

Premiums are related to the products that are offered for free or at a much lower price as an incentive to buy the brand which is not characterized as market recognition. Although it is not a valuable gift, the task of the premium is manifested in attracting a larger number of customers, increasing sales and achieving a better position in relation to competitors.

Coupons can be delivered door-to-door, appear in magazines and newspapers or on the packaging of the product, and as such are used to encourage the test buy or repurchase. They are very present form of sales promotion, although usually less effecient than discount in raising the initial sales as preventing current savings and do not attract existing customers. Coupons for purchase another product at a discounted price mean that under this form of cooperation the coupon on the package or bonus coupon allows the consumer to buy another product at a discounted price (Jefkins, 2002).

The promotional campaign for charity becomes an integral element of public relations that can have a good or bad influence on the performance of the company, which depends of how the program is 
planned and implemented. Companies have access to different types of competitions, lottery and prize games. The first type of reward requests the participants a certain degree of skills and knowledge where participation is conditioned by shopping. Contests lotteries don't ask for any skills or knowledge but their outcome depends purely out of luck, and success of the games depends on the value or originality of awards and delivered bonus coupon (Jefkins, 2002).

Great progress was made by the introduction of a retail loyalty card. Every time the money is spent in a retail store, you get the points which can be used for purchase in the store in the future. The intention is to attract customers to again visit the store, but they are also an excellent source of information about customers, which the company use in direct marketing campaigns. Cards can only apply to one company, but there are examples where companies are joining as a result of the joint venture and they form one card (Jobber and Fahy, 2006).

\section{EMPIRICAL EVIDENCE}

The research was conducted on the territory of Macva region on a random sample of 100 respondents. The research period lasted two months, January and February 2015. Respondents who participated in the research had to anonymously give answers to questions they were asked in the survey. The initial portion of the survey included questions concerning respondents opinions about the frequency of promotional activities which are applied or are not applied by retail chains. Other questions concern the attitudes of respondents on the representation of resources and the impact of individual sales promotion activities on their purchasing decisions.

Figure 1, shows the responses to the question on promotional activities in retail chains in Serbia, where about half of the respondents think that there are enough promotional activities, while the other half do not agree with this statement. This question checks how informed consumers are and their awareness of how sales improvement is really used. According to the survey results, with the aim of achieving more competitive position, companies should intensify various forms of sales promotion directed at consumers.

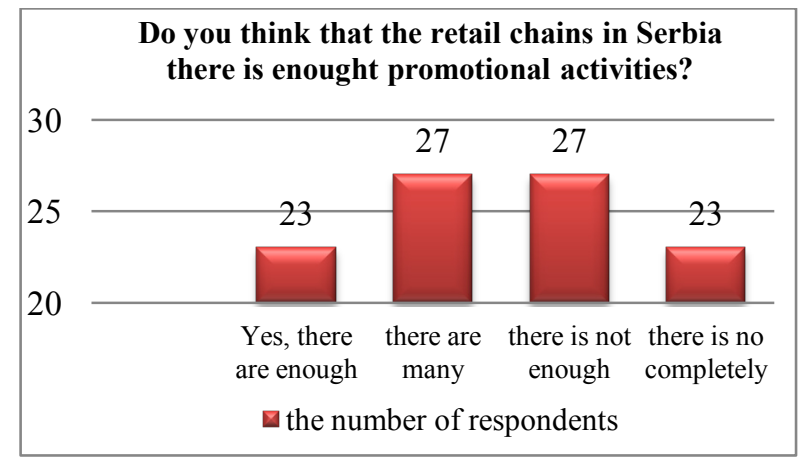

Figure 1: Responses to the question on promotional activities in retail chains in Serbia

(Source: Authors)

The impact of price reductions on product selection

wholly $\square$ predominantly $\square$ a little $\square$ not a little

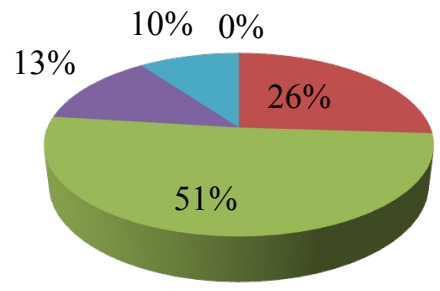

Figure 2: Answers to the question about the impact of price reduction on the customer choice

(Source: Authors)

When asked how price reductions affect the selection of products, $51 \%$ of respondents do not remain indifferent to this form of sales promotion, $26 \%$ of them are fully committed to these steps of the chains, while only $23 \%$ of respondents remain indifferent to price reductions. Based on the responses we see that it confirms that the price reduction sales promotion technique that brings the best results. We see that $90 \%$ of price reduction affect to some extent, and only $10 \%$ do not affect at all. This is shown in Figure 2. Consumers increasingly expect various campaigns and discount prices, which is a very important piece of information for retail chains when acquiring an enviable position compared to its competitors.

Asked about the impact of promotions, tastings and demonstrations in choosing products, about $70 \%$ of respondents agreed that these types of promotional activities do not have particular impact on them when purchasing and product selection. On the other hand, about $30 \%$ of respondents believe that this means of sale represent an important aspect when determining purchase. This is shown in Figure 3. Considering that the promotion, tastings and demonstrations require substantial financial investment by the company, it can be concluded 
that these types of sales promotion are not the right choice for companies seeking an enviable competitive position in a particular market.

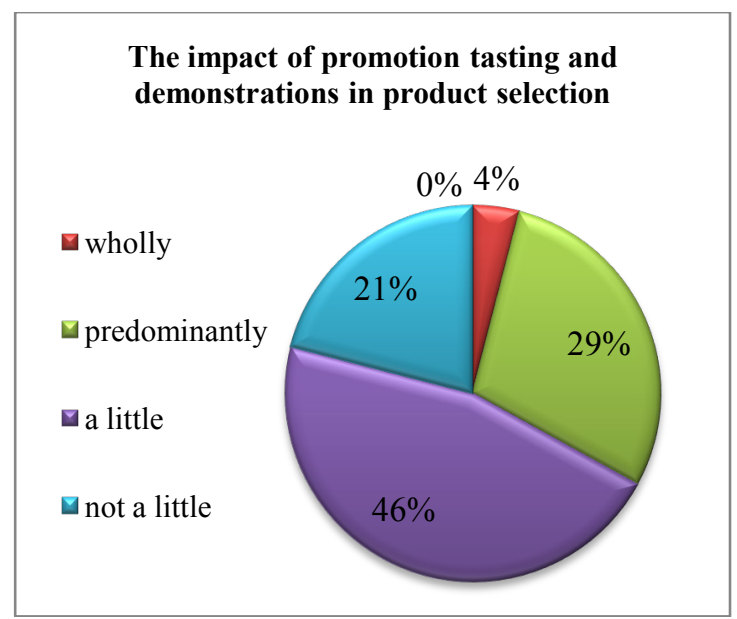

Figure 3: Answers to the question about the impact of promotions, tastings and demonstrations on product selection

(Source: Authors)

Respondents had the opportunity to give their opinion on the impact of winning games during the selection of products, including $46 \%$ of them showing signs of indifference to the rewards that follow along with the expected products. In contrast, few of the respondents agreed that the awards represent a very important motivating factor in the choice of products, while the remaining respondents, more precisely $40 \%$ of them considered that the award is not required in case of a tested product. This is shown in Figure 4. According to the results that sweepstakes do not have such a strong influence, but certainly lead to a significant increase in traffic of the product. Contests are most important when you want to pick up the level of sales in the short term. Also, on the reward depends how many of the participants will be involved in the competition, the more valuable the prizes, the higher sales of these products.

The next question that the respondents encountered was related to the amount of the product and its price or, what is the impact on the price of the quantity that will be purchased. Most of the respondents thought that the price has a direct impact on the amount of items purchased, $61 \%$ of them. Those who are of the opposite opinion, and who do not buy a larger amount due to the lower price of the product, with $39 \%$ of respondents. This is shown in Figure 5. Based on respondents answers can be concluded that the products that are on sale, or offered to consumers at promotional prices represent a very successful form of sales promotion and build trust between the customer - the company, which certainly contributes to a better and stable position of a company in the market.

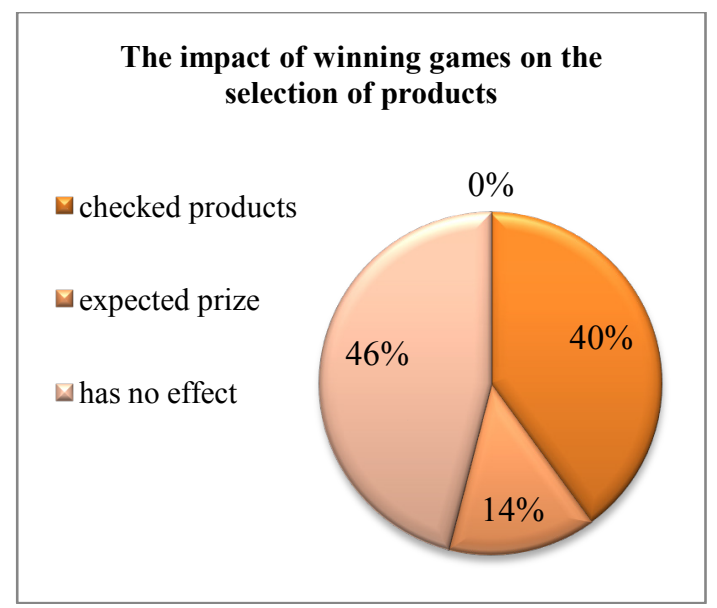

Figure 4: Answers to the question about the impact of games on the selection of reward products (Source: Authors)

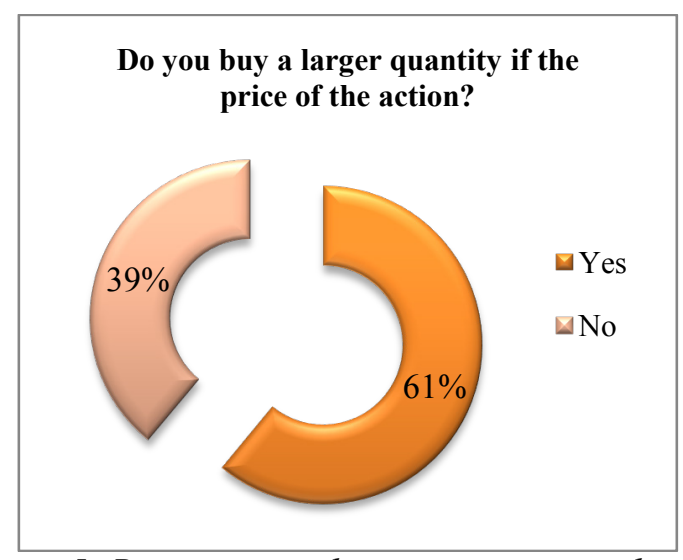

Figure 5: Responses to the question on purchase of larger quantities of the product if its price per share

(Source: Authors)

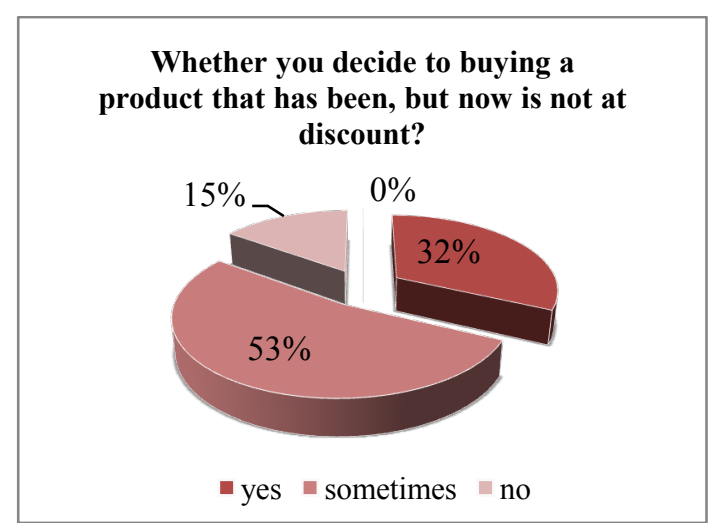

Figure 6: Answers to the question about buying a product that has been, but now is not at discount (Source: Authors)

The next question that respondents had the opportunity to give their judgment effectively 
represents a kind of supplement or continuation of the previous questions. This is shown in Figure 6. In fact, considering how the interest of consumers was caused by promotions, it is crucial for companies to determine the attractiveness of the identical product that will be offered at market prices. If we take into account that $53 \%$ of respondents generally returns to "promotional" products and they add the $32 \%$ of respondents who will definitely opt for the beforementioned products, we are given the fact that a large number of companies choose for price action as a means of sales promotion. On the other hand, we should have in mind that the decisions of consumers are directly caused by the fact what type the product is in question and how the same customer needs that.

\section{CONCLUSIONS}

Variations of enforcement action sales promotion are diverse and only one walk in the supermarket can detect several programs that act at the same time. Also, going to the bank, gas station, reveals obvious ways to attract the attention of clients. The percentage of consumers that can not claim that they are immune or to resist the challenge of free gifts, to buy something at a discounted price or special offer is small. In recent years, the popularity of some offers, significantly decreased, while some older forms have not returned.

The results showed that half of the respondents believe that the company did not give their maximum in the area of sales promotion. As price represents a factor that depends on the chain companies, consumers increasingly expect various discounts from them, which is a very important item for retail chains in the acquisition enviable position compared to its competitors. Sweepstakes have not shown themselves as a decisive factor for the purchase of certain products by the consumer, but it can definitely lead to a significant increase in turnover of the product. Bearing in mind that each company has financially limited funds intended for promotional activities, for the company is an important result of research which shows that consumers are showing signs of interest in wine tasting or product demonstrations. Another aspect of the research that affects the business of the company is the fact that consumers are very interested in promotional products, or products that are offered at significantly lower prices than the market. The impact of this type of promotional activity is multifaceted, bearing in mind that research shows that consumers are showing signs of interest for the same products outside of the promotional period.

The business of every company is reflected in the same position which it assumes in relation to its competitors. In order for this position to be at the highest possible level, it is necessary to determine in advance the plan for using the funds of sales promotion and thus ensure the continuity and synchronization of purchases or sales, and thus ensure the primary objective of the company.

\section{REFERENCES}

Begen, F. (2004). Psihologija u marketingu. Beograd: Clio.

Božidarević, D. \& Salai, S. (2009). Marketing istraživanje. Subotica: Ekonomski fakultet Subotica. Jefkins, F. (2002). Oglašavanje. Beograd: Clio.

Jobber, D. \& Fahy, J.(2006). Osnovi marketinga. Beograd: DATA STATUS.

Kotler, P. \& Kelle, K.L.(2006). Marketing menadžment. Beograd: DATA STATUS.

Maričić, B. (2008). Ponašanje potrošača. Beograd: Centar za izdavačku delatnost Ekonomskog fakulteta u Beogradu.

Smith, R. P. (2002). Marketinške komunikacije. Beograd: Clio.

Stanković, Lj., Đukić, S. \&Popović, A. (2012). Razvoj društveno odgovornog marketinga. Marketing, 43(3), 181-189.

Šapić, D.(2002). Marketing na internetu. Beograd: Peščanik $\mathrm{M}$. 